Fictions Inc. 



\section{Fictions InC.}

The Corporation in Postmodern Fiction, Film, and Popular Culture

RALPH CLARE

Rutgers University Press

NEW BRUNSWICK, NEW JERSEY, AND LONDON 
Clare, Ralph, 1975-

Fictions Inc. : the corporation in postmodern fiction, film, and popular culture / Ralph Clare.

pages $\mathrm{cm}$

Includes bibliographical references and index.

ISBN 978-0-8135-6588-o (hardcover : alk. paper)

ISBN 978-0-8135-6587-3 (pbk. : alk. paper)

ISBN 978-0-8135-6589-7 (e-book)

1. American fiction-2oth century-History and criticism. 2. Capitalism in literature.

3. Corporations in literature. 4. Industries in literature. 5. Motion pictures-Social aspects-United States-History-2oth century. 6. Motion pictures-United StatesPlots, themes, etc. 7. Postmodernism-United States-History-2oth century. I. Title. II. Title: Corporation in postmodern fiction, film, and popular culture.

PS374.C36C53 2014

$813^{\prime} \cdot 5093553-\mathrm{dc} 23$

2014000068

A British Cataloging-in-Publication record for this book is available from the British Library.

A version of chapter 5 originally appeared in Studies in the Novel 45.1 (2013): 102-122, and a version of chapter 6 appeared in Critique: Studies in Contemporary Fiction 54.1 (2012): 28-45. The author wishes to thank both journals for the permission to reprint the essays in modified form here. The Hal Leonard Corporation has granted permission to use the lyrics from Stereolab's "Wow and Flutter," written by Tim Gane and Laetitia Sadler, from the album Mars Audio Quintet (Elektra, 1994). The University of California Press has given permission to use several lines from Rainer Maria Rilke's "The Swan” from Rilke: Selected Poems. Trans. C.F. MacIntyre. U of California P, 1940.

Copyright $\odot 2014$ by Ralph Clare. All rights reserved

No part of this book may be reproduced or utilized in any form or by any means, electronic or mechanical, or by any information storage and retrieval system, without written permission from the publisher. Please contact Rutgers University Press, 106 Somerset Street, New Brunswick, NJ 08901. The only exception to this prohibition is "fair use" as defined by U.S. copyright law.

Visit our website: http://rutgerspress.rutgers.edu

Manufactured in the United States of America

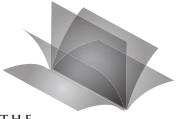

A M E R I C A N

LITERATURES

I N I T I A T I V E
A book in the American Literatures Initiative (ALI), a collaborative publishing project of NYU Press, Fordham University Press, Rutgers University Press, Temple University Press, and the University of Virginia Press. The Initiative is supported by The Andrew W. Mellon Foundation. For more information, please visit www.americanliteratures.org. 
For my parents 

The first thing I did was make a mistake. I thought

I had understood capitalism, but what I had done

was assume an attitude-melancholy sadness-

toward it. This attitude is not correct.

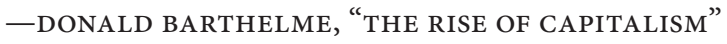


